\title{
THE LATE QUATERNARY SEDIMENTARY RECORD OF REYKJANES RIDGE, NORTH ATLANTIC
}

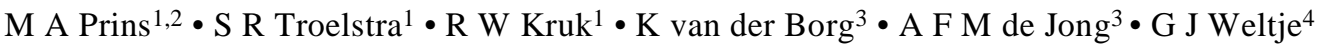 \\ ABSTRACT. Variability in surface and deep ocean circulation in the North Atlantic is inferred from grain-size characteristics \\ and the composition of terrigenous sediments from a deep-sea core taken on Reykjanes Ridge, south of Iceland. End-member \\ modeling of grain size data shows that deep-ocean circulation in this area decreased significantly during periods of maximum \\ iceberg discharge. The episodes of reduced circulation correlate with the cold and abrupt warming phases of the Dansgaard- \\ Oeschger cycles as recognized in the Greenland ice cores.
}

\section{INTRODUCTION}

Monitoring of past ocean circulation and associated heat and nutrient transport is a key objective for understanding of causes and mechanisms of climate change. For the recognition and accurate timing of the climatic signals, sedimentary records from high deposition rate areas are needed. Deep-sea cores obtained during the 1997 Denmark Strait Expedition (Troelstra et al. 1997) fit this purpose and have the potential to establish a direct link with Late Quaternary atmospheric climate change as recorded in the Greenland ice cores (e.g. Johnsen et al. 1992; Grootes et al. 1993). This paper focuses on the chronology and the sedimentology of a core taken on Reykjanes Ridge, south of Iceland.

The grain-size of the silt fraction of current-sorted sediments is commonly used to reconstruct variations in the vigor of deep-ocean circulation (e.g. McCave et al. 1995a, 1995b; Bianchi and McCave 1999). The sand content of North Atlantic sediments is widely applied as a proxy for the input of ice-rafted detritus which is related to surface-water conditions (e.g. Bond and Lotti 1995; Bond et al. 1997). Ambiguous paleoclimate inferences may be drawn from the texture of these sediments if both deep-ocean currents and icebergs supplied the sediments. End-member modeling of grain-size distributions of such sediments in core DS97-2P allows the objective unravelling of the signals of varying bottom-current speed and varying input of ice-rafted detritus (Prins et al. 2001).

\section{MATERIAL AND METHODS}

Core DS97-2P was collected during the Dutch Denmark Strait expedition in 1997 with the R/V "Professor Logachev" (Troelstra et al. 1997). The core (10.4 m length) was obtained from Reykjanes Ridge $\left(58^{\circ} 56.327^{\prime} \mathrm{N}, 30^{\circ} 24.590^{\prime} \mathrm{W}\right)$ from a water depth of $1685 \mathrm{~m}$ (Figure 1). A digital image of the core and a magnetic susceptibility (1-cm resolution) record were obtained with a GEOTEK multisensor core logger. Chemical composition ( $\mathrm{Ca}, \mathrm{Ti}, \mathrm{K}$ intensities) was measured with the CORTEX $\mathrm{X}$-ray fluorescence core scanner at a $1-\mathrm{cm}$ resolution (Jansen et al. 1998). Ca intensity was calibrated to measured carbonate content $\left(\mathrm{CaCO}_{3}(\mathrm{wt} \%)=0.9 \times \mathrm{Ca}(\mathrm{c} / \mathrm{s} \%)-4.2 ; \mathrm{r}^{2}=0.95\right)$.

A Fritsch A22 Laser Particle Sizer was used to analyze the grain-size distribution $(0.15-1189 \mu \mathrm{m})$ at a $5-\mathrm{cm}$ interval for the complete core and at a $1 \mathrm{~cm}$ resolution for two specific intervals. Organic carbon, carbonate, and biogenic opal were removed prior to the grain-size analysis by treatment with excess $\mathrm{H}_{2} \mathrm{O}_{2}, \mathrm{HCl}$ and $\mathrm{NaOH}$, respectively. Details on the particle sizer used are given in Konert and Vandenberghe (1997). A Finnigan MAT 251 mass spectrometer combined with an automatic Finni-

\footnotetext{
${ }^{1}$ Faculty of Earth Sciences, Vrije Universiteit, Amsterdam, the Netherlands

${ }^{2}$ Corresponding author. Email: prim@geo.vu.nl.

${ }^{3}$ Faculty of Physics and Astronomy, University Utrecht, Utrecht, the Netherlands

${ }^{4}$ Faculty of Civil Engineering and Applied Geosciences, Delft University of Technology, Delft, the Netherlands
} 


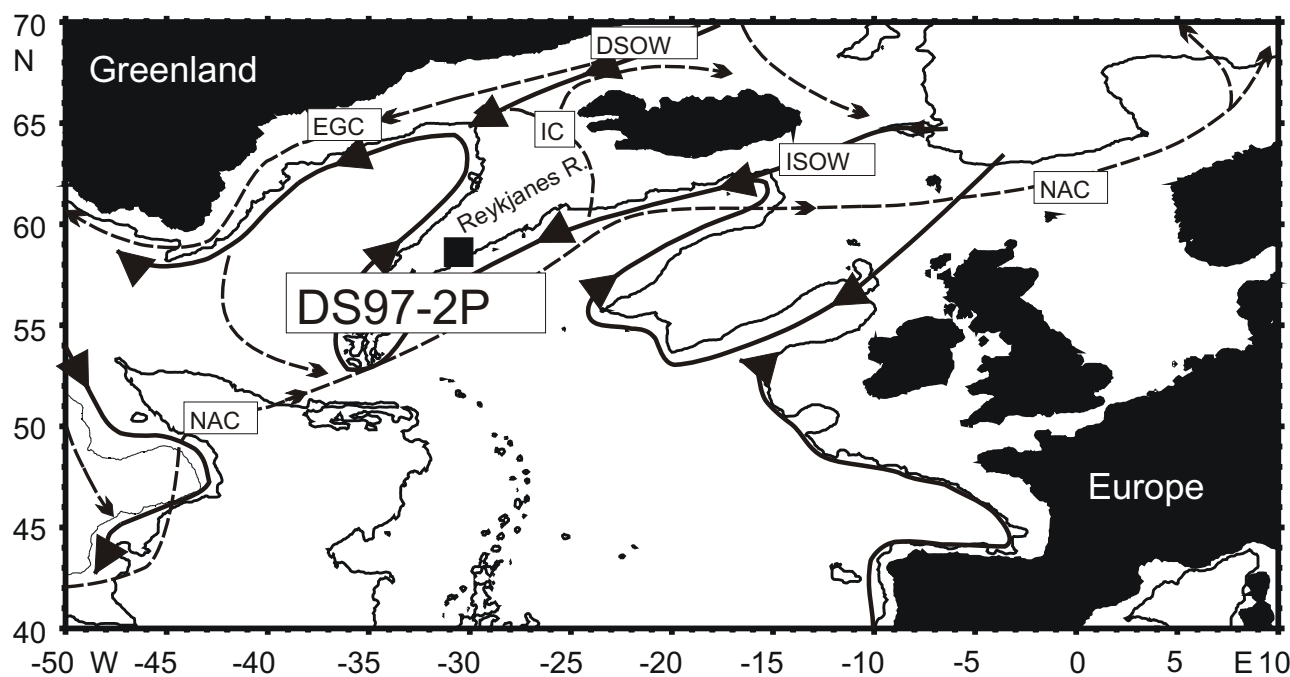

Figure 1 Location of core DS97-2P on Reykjanes Ridge. Deep water flow paths are indicated by solid lines: e.g. Denmark Strait Overflow Water (DSOW), Iceland-Scotland Overflow Water (ISOW). Surface currents are indicated by dashed lines: e.g. North Atlantic Current (NAC), Irminger Current (IC), East Greenland Current (EGC). Terrigenous sediments at site DS97-2P are mainly supplied by ISOW and EGC.

gan MAT carbonate preparation line was used to analyze the stable oxygen/carbon isotope composition of the planktonic foraminiferal species Globigerina bulloides and Neogloboquadrina pachyderma (sinistral) at a $10-\mathrm{cm}$ interval.

The chronology is based on 20 accelerator mass spectrometry (AMS) radiocarbon dates of planktonic foraminiferal samples that were taken from the upper 7 meters in core DS97-2P (Table 1). The AMS ${ }^{14} \mathrm{C}$ dates were obtained from ${ }^{14} \mathrm{C}$ analysis with the Utrecht AMS facility (Van der Borg et al. 1997). Carbon dioxide extracted with $4 \% \mathrm{HCl}$ from the foraminifera samples was used for the analysis. Calendar age ranges (1-sigma probability), assuming a 400-yr marine reservoir age, were obtained by using the computer program Calib 4.2 (Stuiver and Reimer 1993). AMS ${ }^{14} \mathrm{C}$ dates older than $21,000{ }^{14} \mathrm{C}$ years were calibrated using a regression equation, which describes the relationship between ${ }^{14} \mathrm{C}$ and $\mathrm{Th} / \mathrm{U}$ ages (E Bard, 4th International Congress on Paleoceanography, Kiel, 1992). The AMS ${ }^{14} \mathrm{C}$ results are listed in Table 1 .

\section{RESULTS}

The age model of core DS97-2P is based on a combination of AMS ${ }^{14} \mathrm{C}$ dates and $\delta^{18} \mathrm{O}$ stratigraphy. The AMS ${ }^{14} \mathrm{C}$ dates display several age reversals, the largest reversions occurring in the lower part of the record. Some of these dates have therefore been omitted for the construction of the (preliminary) age model (Figure 2A, Table 1). The high sedimentation rates (average $40 \mathrm{~cm} / \mathrm{ka}$; varying between 4 $89 \mathrm{~cm} / \mathrm{ka}$ ) allow reconstruction of climate variability on multi-decadal to millennial time scales (Figure 2B). The age model of the record below $7 \mathrm{mbsf}$ was constructed by extrapolation of the LSR (see Figure 5). The AMS ${ }^{14} \mathrm{C}$ dates and the G. bulloides and $N$. pachyderma $(\sin ) \delta^{18} \mathrm{O}$ records (Figure 3A) permit distinction between the Holocene ( $\sim-4.2 \mathrm{mbsf}$ ) and the Glacial record (below $\sim 4.2 \mathrm{mbsf}$ ).

The carbonate and magnetic susceptibility records (Figure 3B, C) of core DS97-2P clearly show the division between the Holocene and the Late Glacial sequences. On top of the glacial/interglacial 
Table 1 Accelerator mass spectrometry ${ }^{14} \mathrm{C}$ dates and calibrated ages for DS97-2P

\begin{tabular}{llllll}
\hline Sample number & $\begin{array}{l}\text { Depth } \\
(\mathrm{cm})\end{array}$ & Material & $\begin{array}{l}\text { UtC } \\
\text { number }\end{array}$ & $\begin{array}{l}\text { Uncorrected } \\
{ }^{14} \text { C age (BP) }\end{array}$ & $\begin{array}{l}\text { Calendar age, one sigma range } \\
(\mathrm{cal} \mathrm{BP})^{\mathrm{a}}\end{array}$ \\
\hline DS97-2p-11.02 & 1 & Planktonic forams & 9654 & $1440 \pm 160$ & $1165(966) 823^{\mathrm{b}, \mathrm{c}}$ \\
DS97-2p-11.12 & 10 & Planktonic forams & 9655 & $1380 \pm 60$ & $967(923) 887^{\mathrm{b}}$ \\
DS97-2p-11.22 & 18 & Planktonic forams & 9656 & $1800 \pm 80$ & $1410(1328) 1271^{\mathrm{b}}$ \\
DS97-2p-10.12 & 57 & Planktonic forams & 9657 & $2680 \pm 90$ & $2472(2341) 2294^{\mathrm{b}}$ \\
DS97-2p-10.52 & 96.5 & Planktonic forams & 9658 & $4020 \pm 60$ & $4115(4047) 3950^{\mathrm{b}}$ \\
DS97-2p-10.82 & 126 & Planktonic forams & 9659 & $4840 \pm 90$ & $5281(5131) 4974^{\mathrm{b}}$ \\
DS97-2p-09.12 & 157.5 & Planktonic forams & 9660 & $5920 \pm 50$ & $6387(6307) 6278^{\mathrm{b}}$ \\
DS97-2p-08.02 & 247 & Planktonic forams & 9661 & $7560 \pm 60$ & $8091(7999) 7942^{\mathrm{b}}$ \\
DS97-2p-08.82 & 326 & Planktonic forams & 9662 & $8370 \pm 60$ & $8945(8890) 8813^{\mathrm{b}}$ \\
DS97-2p-07.72 & 415.5 & Planktonic forams & 9663 & $10,860 \pm 70$ & $12,611(12,320,12,203,12,185) 11,763^{\mathrm{b}, \mathrm{c}}$ \\
DS97-2p-07.92 & 435 & Planktonic forams & 9664 & $10,810 \pm 70$ & $12,585(12,285,12,238,12,121) 11,750^{\mathrm{b}}$ \\
DS97-2p-06.12 & 455.5 & Planktonic forams & 9665 & $11,540 \pm 80$ & $13,152(13,014) 12,962^{\mathrm{b}}$ \\
DS97-2p-06.42 & 484.5 & Planktonic forams & 9666 & $21,030 \pm 170$ & $24,935^{\mathrm{c}, \mathrm{d}}$ \\
DS97-2p-06.52 & 494 & Planktonic forams & 9667 & $19,760 \pm 100$ & $23,246(22,842) 22,475^{\mathrm{b}}$ \\
DS97-2p-06.82 & 524.5 & Planktonic forams & 9668 & $22,140 \pm 280$ & $26,203^{\mathrm{c}, \mathrm{d}}$ \\
DS97-2p-06.92 & 534.5 & Planktonic forams & 8869 & $20,170 \pm 140$ & $23,774(23,314) 22,919^{\mathrm{b}}$ \\
DS97-2p-05.40 & 582.5 & Planktonic forams & 9669 & $23,400 \pm 220$ & $27,625^{\mathrm{d}}$ \\
DS97-2p-05.80 & 622.5 & Planktonic forams & 8870 & $29,900 \pm 300$ & $34,664^{\mathrm{c}, \mathrm{d}}$ \\
DS97-2p-04.32 & 675 & Planktonic forams & 8871 & $31,300 \pm 280$ & $36,115^{\mathrm{c}, \mathrm{d}}$ \\
DS97-2p-04.52 & 694.5 & Planktonic forams & 9670 & $26,240 \pm 280$ & $30,761^{\mathrm{d}}$ \\
\hline
\end{tabular}

${ }^{a}$ Radiocarbon ages were corrected by -400 yr to account for the age of the surface ocean reservoir.

${ }^{\mathrm{b} C a l e n d a r}$ ages calibrated using Calib 4.2, Stuiver and Reimer (1993).

${ }^{\mathrm{c}}$ Age is stratigraphically not consistent; data not incorporated in preliminary age model.

${ }^{\mathrm{d}}$ Calendar ages calibrated using regression equation which describes the relationship between ${ }^{14} \mathrm{C}$ and $\mathrm{Th} / \mathrm{U}$ ages (E Bard, 4th International Congress on Paleoceanography, Kiel, 1992): cal. age $=-5.85 \times 10^{-6}\left({ }^{14} \mathrm{C} \text { age }\right)^{2}+1.39\left({ }^{14} \mathrm{C}\right.$ age $)-1807$.

trend in sediment composition, both data sets show high-amplitude and high frequency variations in composition in the glacial interval (>4.2 mbsf). The positive correlation between magnetic susceptibility and carbonate content in this part of the record indicates that variation in magnetic susceptibility reflects variations in composition rather than content of the terrigenous fraction. The positive correlation between the $\mathrm{Ti} / \mathrm{K}$ ratio (indicative of variations in sediment source or grain-size characteristics; Figure 3D) and the magnetic susceptibility records supports this idea.

Very distinct sand-rich layers of ice-rafted sediment characterized by low Ti/K values are present in the glacial section. In contrast, the Holocene record is characterized by low sand content (Figure $3 \mathrm{E})$. High frequency variations in the silt grain-size are recorded throughout the core. A positive correlation between high sand content and coarse silt grain sizes is observed in the glacial part (not shown). Interpretation of the silt record in terms of varying bottom-current speed alone is too simple, as indicated by the end-member modeling results of the grain-size distributions presented by Prins et al. (2001), which are summarized below.

\section{End-Member Modeling of Grain-Size Distributions}

End-member modeling algorithms are aimed at the construction of physical mixing models, which express the input data as mixtures of a limited number of end members with realistic compositions (Weltje 1997). The method allows the distinction and quantification of subpopulations within grainsize distribution data and as such it has been used to discriminate aeolian from fluvial and turbiditic sediments in various deep-marine settings (Prins and Weltje 1999; Prins and Postma 2000; Prins et al. 2000a, 2000b). 

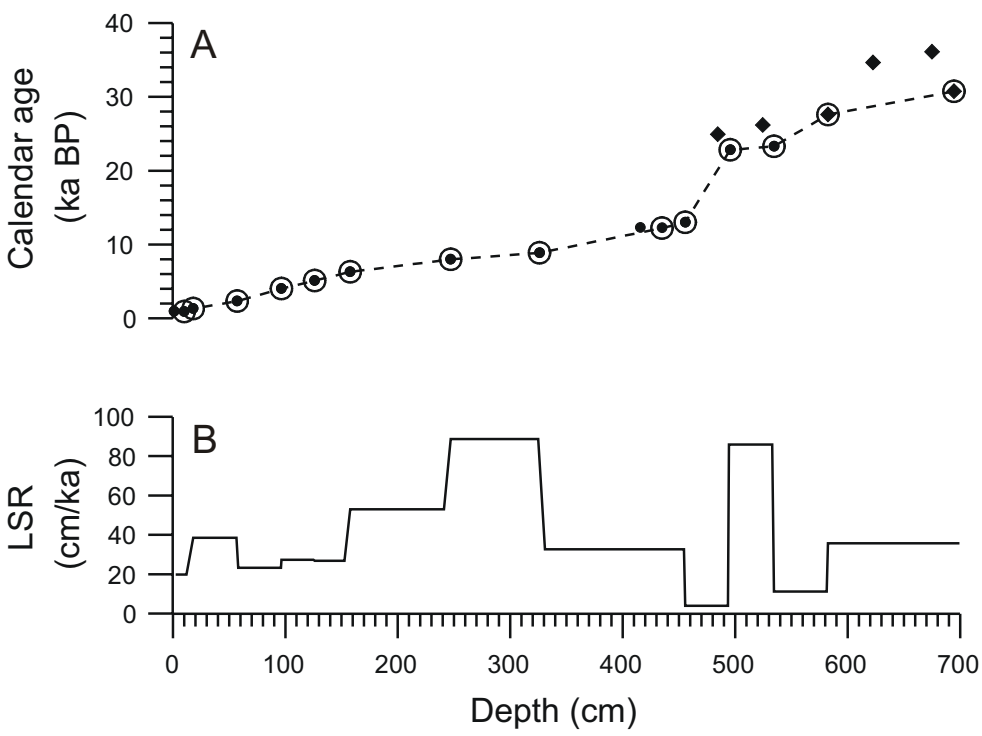

Figure 2 Age model of core DS97-2P: A) Calendar age-depth profile of AMS- ${ }^{14} \mathrm{C}$ dated samples. ${ }^{14} \mathrm{C}$ ages were calibrated according to $(\bullet)$ the Calib 4.2 program (Stuiver and Reimer 1993) or ( $\downarrow$ ) the regression equation which describes the relationship between ${ }^{14} \mathrm{C}$ and $\mathrm{Th} / \mathrm{U}$ ages (E Bard, 4th International Congress on Paleoceanography, Kiel, 1992). Encircled symbols indicate the samples that were used to construct the age model. Data are listed in Table 1. B) Linear-sedimentation rate (LSR).

The end-member modeling algorithm was applied to the data set of grain-size distributions $(n=441)$ of core DS97-2P (Prins et al. 2001). Their modeling results indicate that the sediments are adequately described as mixtures of four end members (Figure 4A). The sand-rich end members EM1 and EM2 resemble combinations of grain size modes that are characteristic of glacial-till deposits (Figure 4B). The most likely way of introduction of sand-sized material in Reykjanes Ridge sediments is by icebergs calved from Greenland and Iceland glaciers (Lackschewitz and WallrabeAdams 1997; Moros et al. 1997; Lackshewitz et al. 1998; Van Kreveld et al. 2000). End members EM1 and EM2 are hence interpreted as ice-rafted detritus (IRD). The well-sorted clayey to fine silty end members EM3 and EM4 are thought to reflect subpopulations of fines supplied and sorted by low-energy deep-ocean flow, i.e. the flow of the Iceland-Scotland Overflow Water (ISOW).

\section{DISCUSSION}

The modeling results indicate that the variations in grain-size distribution reflect both selective transport and deposition of materials from a single source (current-sorted silt), and physical mixing of materials from two different sources (IRD plus current-sorted silt). The relative contribution of the two IRD end members (EM1+EM2) is a proxy for iceberg discharge. The ratio between the relative contributions of the two current-sorted mud end members (EM3/EM4) is a proxy for bottomcurrent flow intensity.

The carbonate content in DS97-2P shows a strong correlation with the $\delta^{18} \mathrm{O}$ record of the GISP2 icecore from Greenland indicating a coupling between atmospheric temperature and oceanic circulation patterns (Figures 5A, B). The end member modeling results suggest that deep-ocean circulation on the Reykjanes Ridge (i.e. formation of ISOW) decreased significantly during periods of maximum 


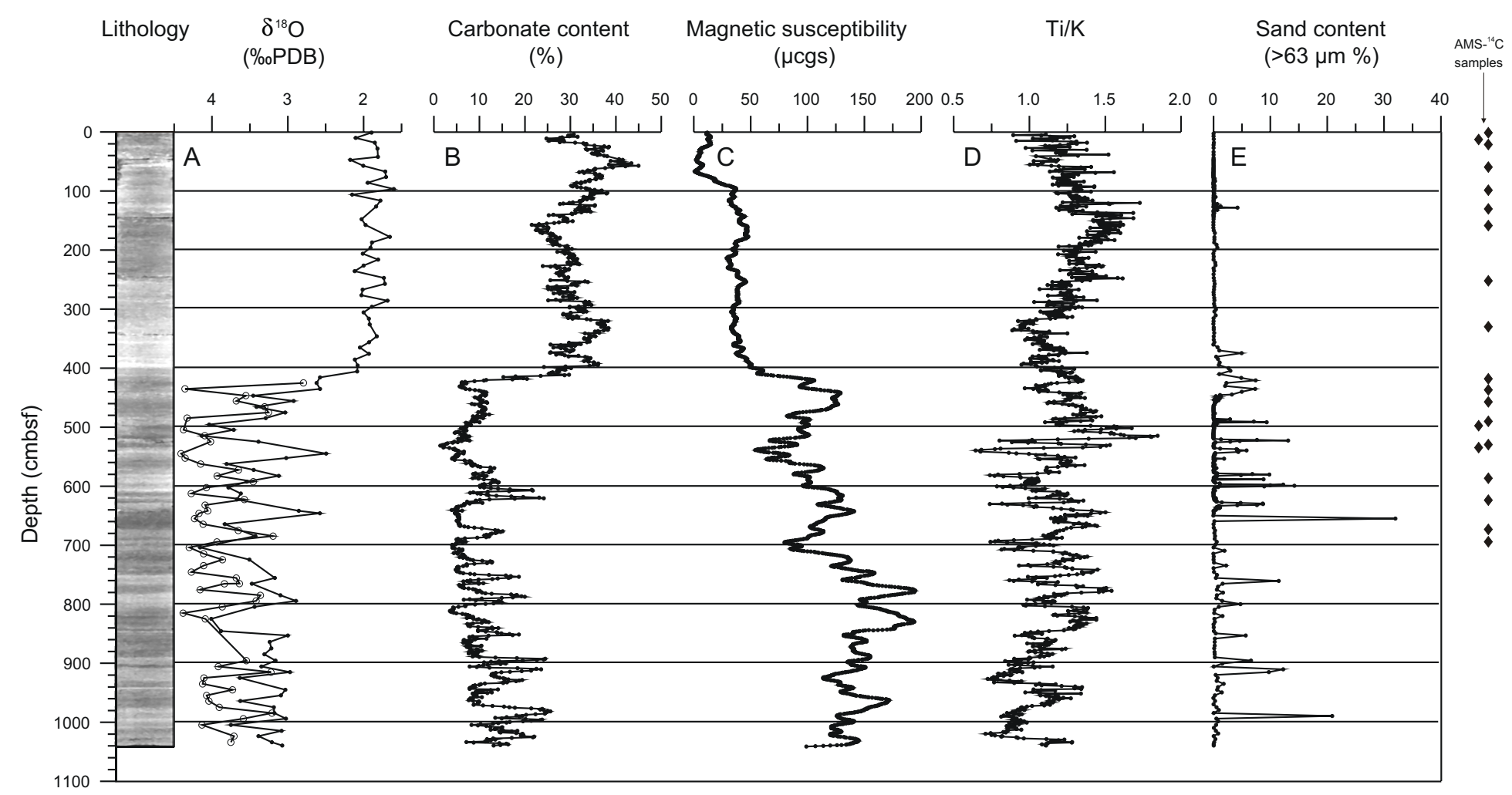

Figure 3 Sediment composition in core DS97-2P: A) $\delta^{18} \mathrm{O}$ of planktonic foraminifera G. bulloides $(\bullet)$ and $N$ pachyderma (sinistral) (O), B) carbonate content, C) magnetic susceptibility, D) Ti/K ratio, E) sand content (>63 um) in terrigenous sediment fraction. The digital image on the left illustrates the variations in lithology. 

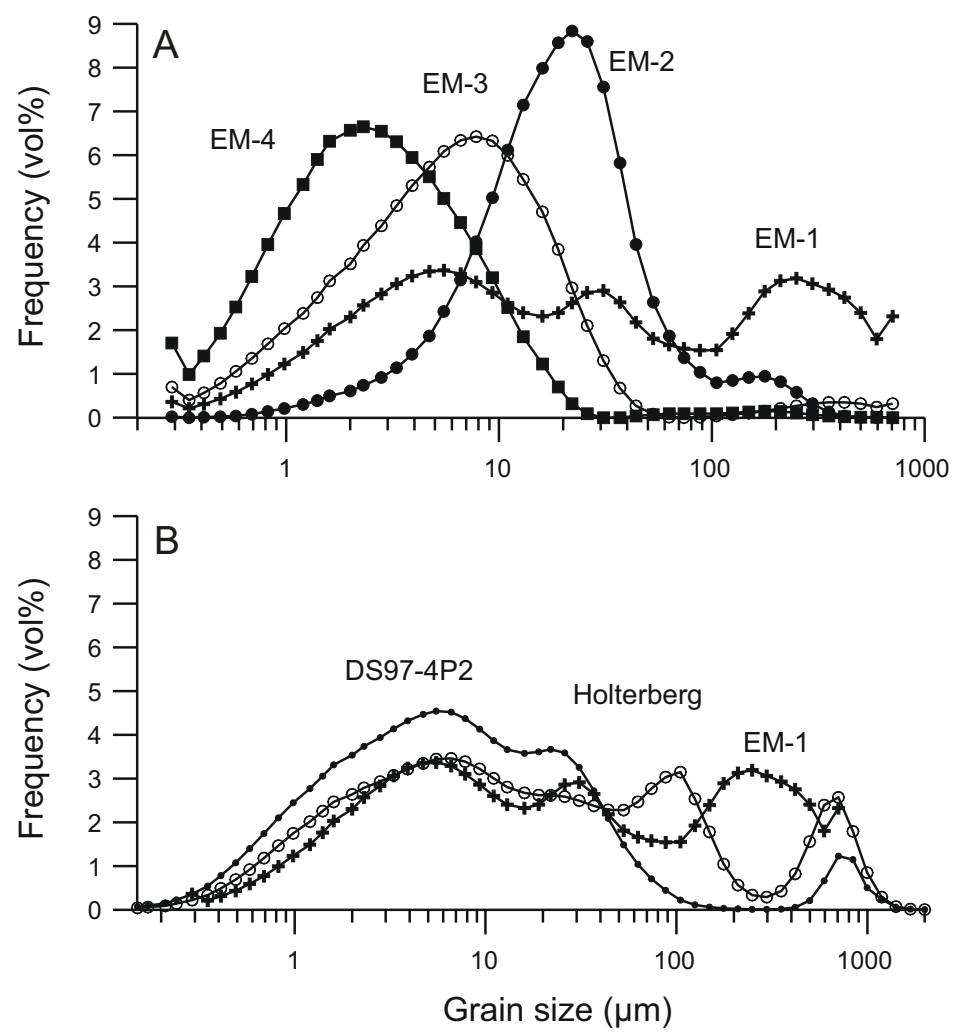

Figure 4 A) Modeled end members according to the four-end-member model for the grain-size distribution data of core DS97-2P (Prins et al. 2001). B) Grain-size distribution of two glacial tills collected near Holterberg (Saalien ice-pushed moraines) in the Netherlands and from core DS97-4P2 from the continental margin of SE Greenland (Troelstra et al. 1997).

iceberg discharge (recurring time 1-3 ka) (Figures 5E, F). The episodes of reduced circulation correlate with the cold and abrupt warming phases of the Dansgaard-Oeschger cycles as recognized in the Greenland ice cores. The observed reduction of deep-water flow coinciding with enhanced iceberg discharges is in agreement with the general consensus that the thermocline ocean conveyor is unstable and sensitive to the fresh water/salt balance of the North Atlantic region (Broecker et al. 1992).

\section{CONCLUSIONS}

The grain-size distributions of Late Glacial-Holocene terrigenous sediments from Reykjanes Ridge are adequately described as mixtures of two poorly sorted ice-rafted detritus end members and two current-sorted silt end members. Ratios of the relative contributions of the end members provide proxies for bottom-current flow intensity and iceberg discharge. The end-member modeling results show that deep-ocean circulation at Reykjanes Ridge decreased significantly during periods of maximum iceberg discharge. The episodes of reduced circulation correlate with the cold and abrupt warming phases of the Dansgaard-Oeschger cycle as recognized in the Greenland ice cores. 


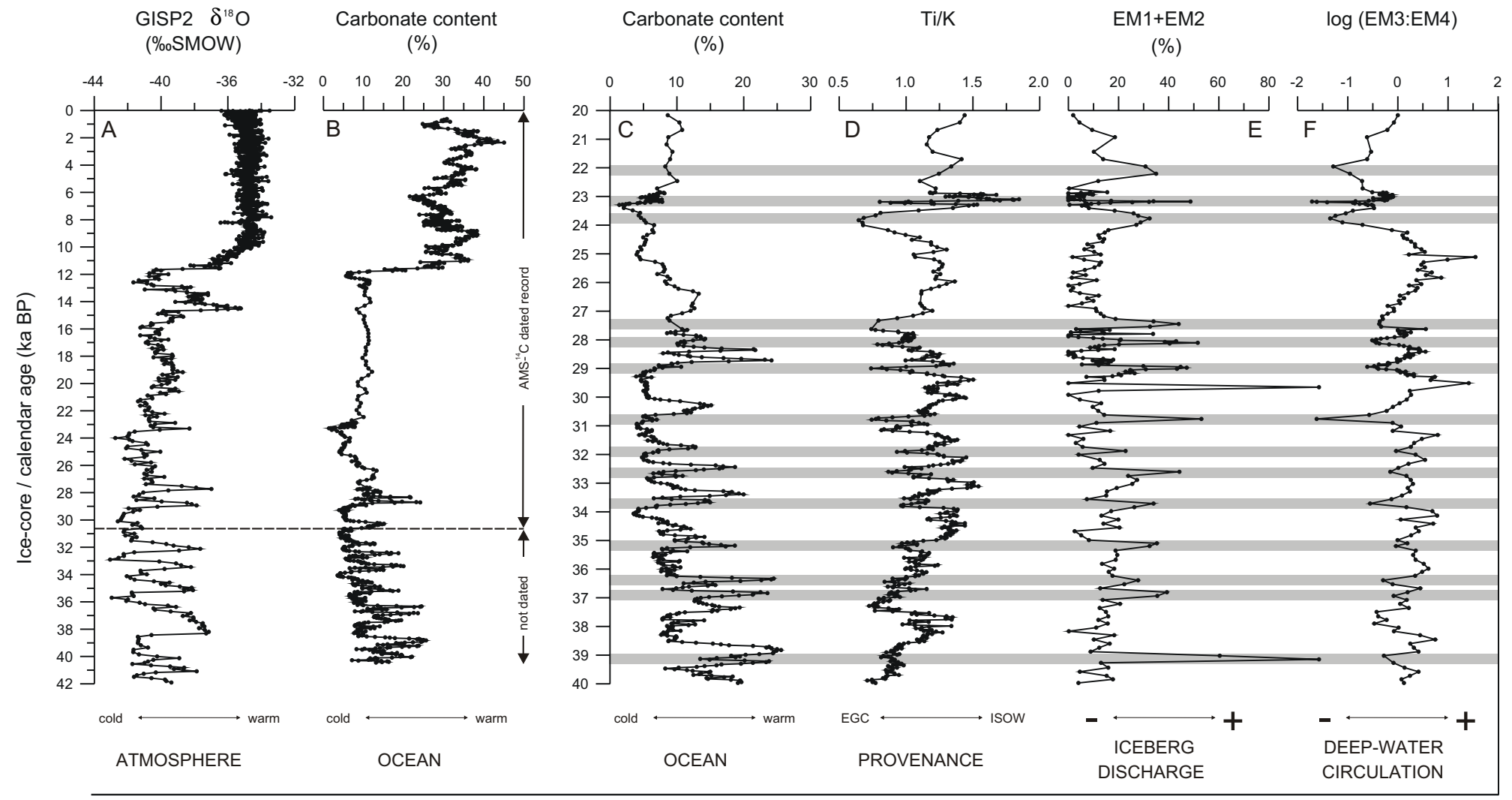

Figure 5 Comparison of A) the $\delta^{18} \mathrm{O}$ record of the GISP2 ice core from Greenland (Grootes et al. 1993) with B) the carbonate record of core DS97-2P. Detailed DS97-2P records (20-40 ka BP) are shown of C) carbonate content, D) Ti/K ratio, E) relative contribution of the two IRD end members (EM1+EM2), and E) logratio between the relative contributions of the two current-sorted mud end members (EM3:EM4). Horizontal bars highlight sediment layers that contain a significant concentration of ice-rafted detritus. 


\section{ACKNOWLEDGMENTS}

The Professor Logachev cruise and subsequent research of the first author were sponsored by NWO/ ALW (CLIVARNET). We thank M Konert for the grain-size analyses, $\mathrm{H}$ Vonhof for his assistance with the mass spectrometer, and S van der Gaast and J-B W Stuut for their assistance with the CORTEX core scanner. A Kuijpers is thanked for useful comments. P Weaver is thanked for helpful and constructive review of the manuscript. This is Netherlands Research School of Sedimentary Geology (NSG) publication no. 20000702.

\section{REFERENCES}

Bianchi GG, McCave IN. 1999. Holocene periodicity in North Atlantic climate and deep-ocean flow south of Iceland. Nature 397:515-17.

Bond GC, Lotti R. 1995. Iceberg discharges into the North Atlantic on millennial time scales during the last glaciation. Science 267:1005-10.

Bond G, Showers W, Cheseby M, Lotti R, Almasi P, deMenocal P, Priore P, Cullen H, Hajdas I, Bonani G. 1997. A pervasive millennial-scale cycle in North Atlantic Holocene and glacial climates. Science 278: 1257-66.

Broecker W, Bond G, Klas M, Clark D, McManus J. 1992. Origin of the northern Atlantic's Heinrich events. Climate Dynamics 6:265-73.

Grootes PM, Stuiver M, White JWC, Johnsen SJ, Jouzel J. 1993. Comparison of oxygen isotope records from the GISP2 and GRIP Greenland ice cores. Nature 366: $552-4$.

Jansen JHF, Van der Gaast SJ, Koster B, Vaars AJ. 1998. CORTEX, a shipboard XRF-scanner for element analyses in split sediment cores: Marine Geology 151: 143-53.

Johnsen SJ, Clausen HB, Dansgaard W, Fuhrer K, Gundestrup N, Hammer CU, Iversen P, Jouzel J, Stauffer B, Steffensen JP. 1992. Irregular glacial interstadials recorded in a new Greenland ice core. Nature 359: 311-13.

Konert M, Vandenberghe J. 1997. Comparison of laser grain size analysis with pipette and sieve analysis: a solution for the underestimation of the clay fraction. Sedimentology 44:523-35.

Lackschewitz KS, Baumann KH, Gehrke B, Wallrab-Adams HJ, Thiede J, Bonani G, Endler R, Erlenkeuser H, Heinemeier J. 1998. North Atlantic ice sheet fluctuations 10,000-70,000 yr ago as inferred from deposits on the Reykjanes Ridge, southeast of Greenland. Quaternary Research 49: 171-82.

Lackschewitz KS, Wallrabe-Adams H-J. 1997. Composition and origin of volcanic ash zones in Late Quaternary sediments from the Reykjanes Ridge: evidence for ash fallout and ice-rafting. Marine Geology 136: 209-24.

McCave IN, Manighetti B, Beveridge NAS. 1995a. Circulation in the glacial North Atlantic inferred from grain size measurements. Nature 374:149-52.

McCave IN, Manighetti B, Robinson SG. 1995b. Sort- able silt and fine sediment size/composition slicing; parameters for paleocurrent speed and paleoceanography. Paleoceanography 10(3):593-610.

Moros M, Endler R, Lackschewitz KS, Wallrabe-Adams H-J, Mienert J, Lemke W. 1997. Physical proporties of Reykjanes Ridge sediments and their linkage to highresolution Greenland Ice Sheet Project 2 ice core data: Paleoceanography 12:687-95.

Prins MA, Bouwer LM, Beets CJ, Troelstra SR, Weltje GJ, Kruk RW, Kuijpers A, Vroon PZ. 2001. Ocean circulation and iceberg discharge in the glacial North Atlantic: inferences from unmixing of sediment size distributions. Geology. Submitted.

Prins MA, Postma G. 2000. Effects of climate, sea level, and tectonics unraveled for last deglaciation turbidite records of the Arabian Sea. Geology 28:375-8.

Prins MA, Postma G, Cleveringa J, Cramp A, Kenyon NH. 2000a. Controls on terrigenous sediment supply to the Arabian Sea during the late Quaternary: the Indus Fan. Marine Geology 169:327-49.

Prins MA, Postma G, Weltje GJ. 2000b. Controls on terrigenous sediment supply to the Arabian Sea during the late Quaternary: the Makran continental slope. Marine Geology 169:351-71.

Prins MA, Weltje GJ. 1999. End-member modeling of siliciclastic grain-size distributions: the late Quaternary record of eolian and fluvial sediment supply to the Arabian Sea and its paleoclimatic significance. In: Harbaugh J, Watney L, Rankey G, Slingerland R, Goldstein R, Franseen E, editors. Numerical experiments in stratigraphy: recent advances in stratigraphic and sedimentologic computer simulations. Society for Sedimentary Geology Special Publication 62:91-111.

Stuiver M, Reimer PJ. 1993. Extended ${ }^{14} \mathrm{C}$ data base and revised Calib $3.0{ }^{14} \mathrm{C}$ age calibration program. Radiocarbon 25(2):215-30.

Troelstra SR, Kuijpers A, the Shipboard Scientific Party. 1997. Late Quaternary paleoceanography of the Denmark Strait Overflow Pathway (SE Greenland Margin). Report of the RV Professor Logachev cruise, Aberdeen (August 16) to Kiel (September 15). Internal report. Amsterdam: Vrije Universiteit. p 1-41.

Van der Borg K, Alderliesten C, de Jong AFM, van den Brink A, de Haas AP, Kersemaekers HJH, Raaymakers JEMJ. 1997. Precision and mass fractionation in 
${ }^{14} \mathrm{C}$ analysis with AMS. Nuclear Instruments and Methods B 123:97-101.

Van Kreveld S, Sarnthein M, Erlenkeuser H, Grootes P, Jung S, Nadeau MJ, Pflaumann U, Voelker A. 2000. Potential links between surging ice sheets, circulation changes, and the Dansgaard-Oeschger cycles in the
Irminger Sea 60-18 kyr. Paleoceanography 15:42542.

Weltje GJ. 1997. End-member modelling of compositional data: numerical-statistical algorithms for solving the explicit mixing problem. Journal of Mathematical Geology 29:503-49. 